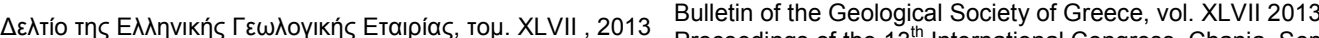
Proceedings of the $13^{\text {th }}$ International Congress, Chania, Sept.

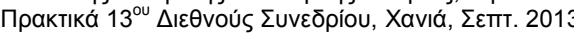
2013

\title{
STRIKE SLIP TECTONICS AND TRANSTENSIONAL DEFORMATION IN THE AEGEAN REGION AND THE HELLENIC ARC: PRELIMINARY RESULTS
}

\author{
Sakellariou D. ${ }^{1}$, Mascle, $\mathrm{J.}^{2}$ and Lykousis V. ${ }^{1}$ \\ ${ }^{1}$ Institute of Oceanography, Hellenic Centre for Marine Research, Greece, sakell@hcmr.gr, \\ vlikou@hcmr.gr \\ ${ }^{2}$ Observatoire Océanologique de Villefranche,France, mascle@obs-vlfr.fr
}

\begin{abstract}
Recently acquired offshore seismic and swath bathymetry data from the Hellenic Arc, the Ionian Sea and the South and North Aegean Sea, including the Hellenic Volcanic Arc and the Cyclades plateau, along with geological and tectonic data from Plio-Quaternary basins exposed on the Hellenic Arc indicate that strike slip tectonics has played a major role in the southwestward extension of the Aegean crustal block, the development of the offshore neotectonic basins and the spatial distribution of the volcanic activity along the Volcanic Arc. Transtensional deformation, accommodated by (sinistral or dextral) strike slip zones and related extensional structures, prevail throughout Plio-Quaternary, since the North Anatolian Fault broke westwards into the North Aegean. Incipient collision of the Hellenic Forearc south of Crete with the Libyan promontory and consequent lateral escape tectonics led to the segmentation of the Hellenic Arc in distinct blocks, which move southwestwards independently from each other and are bounded by strike slip faults. Key words: Plio-Quaternary, fault-zones, neotectonic basins, volcanic activity.
\end{abstract}

\section{Пєрі́ $\eta \psi \eta$}

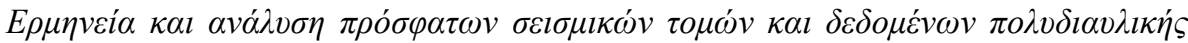

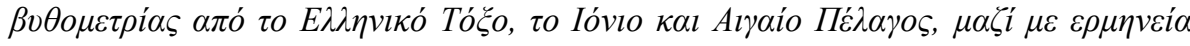

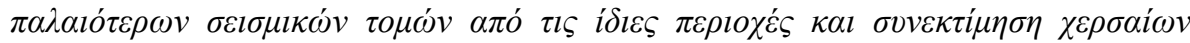

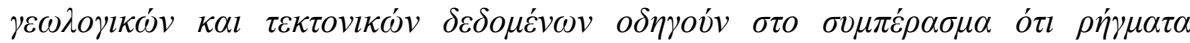

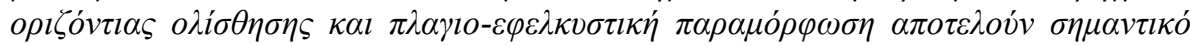

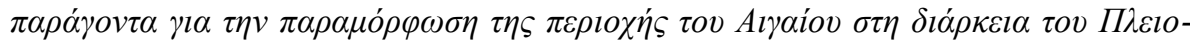

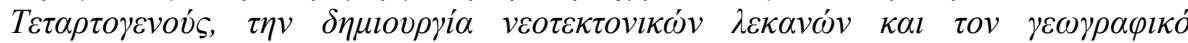

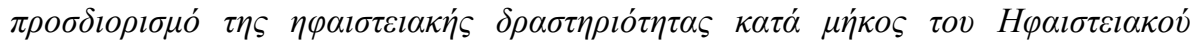

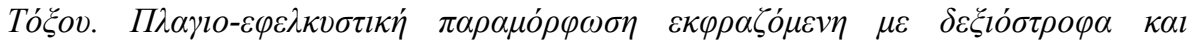

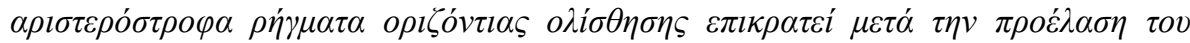

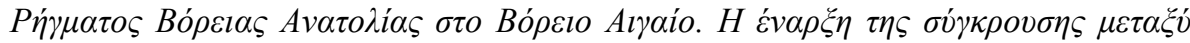

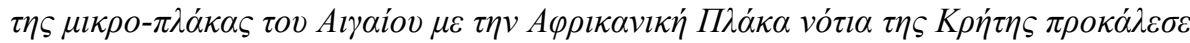

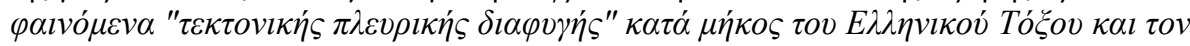

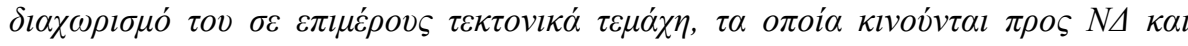

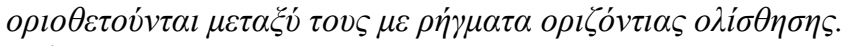

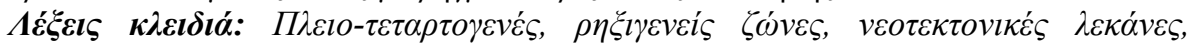
$\eta \varphi \alpha i \sigma \tau \varepsilon l \alpha$.

XLVII. No $2-647$ 


\section{Introduction}

Active tectonics, deformation and high seismicity of the Aegean region have been the subject of many studies during the last 40 years with the aim to understand the implications of plate tectonics for continental deformation. Early studies have used seismologic data, active fault distributions, and seafloor bathymetry to define the major tectonic boundaries of the Aegean and infer the magnitude and sense of relative motions across them (McKenzie, 1972, 1978; Le Pichon and Angelier, 1979, 1981; McKenzie and Jackson, 1983; Taymaz et al., 1991). These and other pioneering studies have shown that earthquake faulting parameters, distribution and sense of motion on mapped active faults display close relationship between them (McKenzie, 1972, 1978; Le Pichon and Angelier, 1981; McKenzie and Jackson, 1983; Taymaz et al., 1991; Goldsworthy et al., 2002) but have not led to the formulation of a widely accepted kinematic model for the Aegean deformation. In the last 20 years GPS surveys have contributed to the quantification of the contemporary deformation of the Aegean region and provided important clues to the understanding of the large-scale kinematics (Billiris et al., 1991; Le Pichon et al., 1995; Davies et al., 1997: Clarke et al., 1998; Briole et al., 2000; McClusky et al., 2000; Nyst \& Thatcher, 2004). The westward extrusion of Anatolia continental block along the North Anatolian Fault, the NNEward subduction of the Eastern Mediterranean lithosphere beneath the Hellenic Arc, the subsequent SSW-NNE extension of the Aegean back-arc region, the collision of NW Greece with the Apulian block in the northern Ionian Sea north of the Kephallonia Fault and the incipient collision with the Libyan promontory south of Crete (Mascle et al, 1999) are the main, active processes. The boundaries of the actively deforming part of the Aegean are defined by the following geotectonic features (Figure 1):

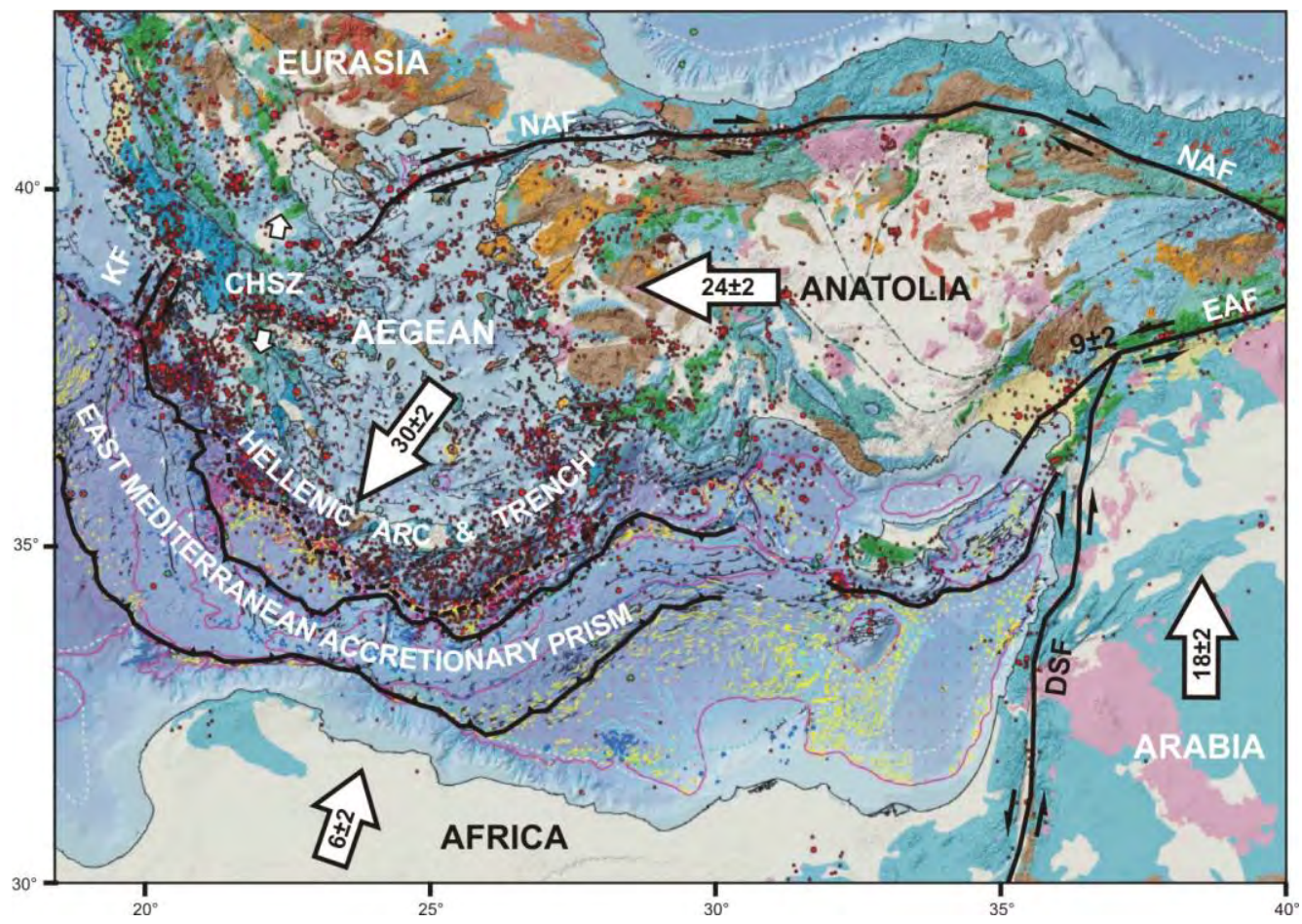

Figure 1 - Morpho-tectonic map of the East Mediterranean (extracted and modified from Mascle \& Mascle, 2012) with main structural features and major tectonic boundaries of the actively deforming Aegean Region. Mean GPS horizontal velocities after McClusky et al (2000). DSF: Dead Sea Fault, EAF: East Anatolian Fault, NAF: North Anatolian Fault, KF: Kephallonia Fault, CHSZ: Central Hellenic Shear Zone. 
1. The westward prolongation of the dextral, strike-slip North Anatolian Fault (NAF) into the Aegean Sea along the North Aegean Trough (NAT) marks the boundary between the relatively non-deforming Eurasian Continent to the north and the deforming Aegean to the south.

2. The Hellenic Trench, a series of deep, elongate basins aligned along the Hellenic Arc defines the southeast, south and west boundary of the Aegean continental block to the East Mediterranean Ridge, the accretionary prism developed above the NE-ward subduction of the East Mediterranean oceanic crust.

3. The Kephallonia Fault (KF), a SSW-NNE trending, dextral, strike slip fault which separates the active part of the Hellenic Arc to the southeast from the inactive one to the north.

4. The Central Hellenic Shear Zone (Papanikolaou \& Royden, 2007), a diffuse boundary, an area of active extensional deformation, which accommodates transferring of stress between the northern tip of the Kephallonia Fault and the southwestern tip of the North Anatolian Fault.

Most of the previous studies (McKenzie, 1972, 1978; McKenzie and Jackson, 1983, 1986; Taymaz et al., 1991; Le Pichon et al., 1995; Armijo et al., 1996; McClusky et al., 2000; Goldsworthy et al., 2002; Nyst \& Thatcher, 2004; Kokkalas et al, 2006) propose that active deformation is mostly concentrated along the boundaries of relatively rigid, smaller, tectonic blocks while they do not exclude isolated zones of deformation in their interior. In this paper we present preliminary results from the interpretation of recently acquired seismic profiles and swath bathymetry data and reevaluation of older seismic data and suggest that NE-SW trending, dextral and sinistral strike slip fault-zones and transtensional deformation has played a major role in the southwestward extension of the Aegean Region during Plio-Quaternary.

\section{Materials and Methods}

In this paper we present preliminary results derived from the:
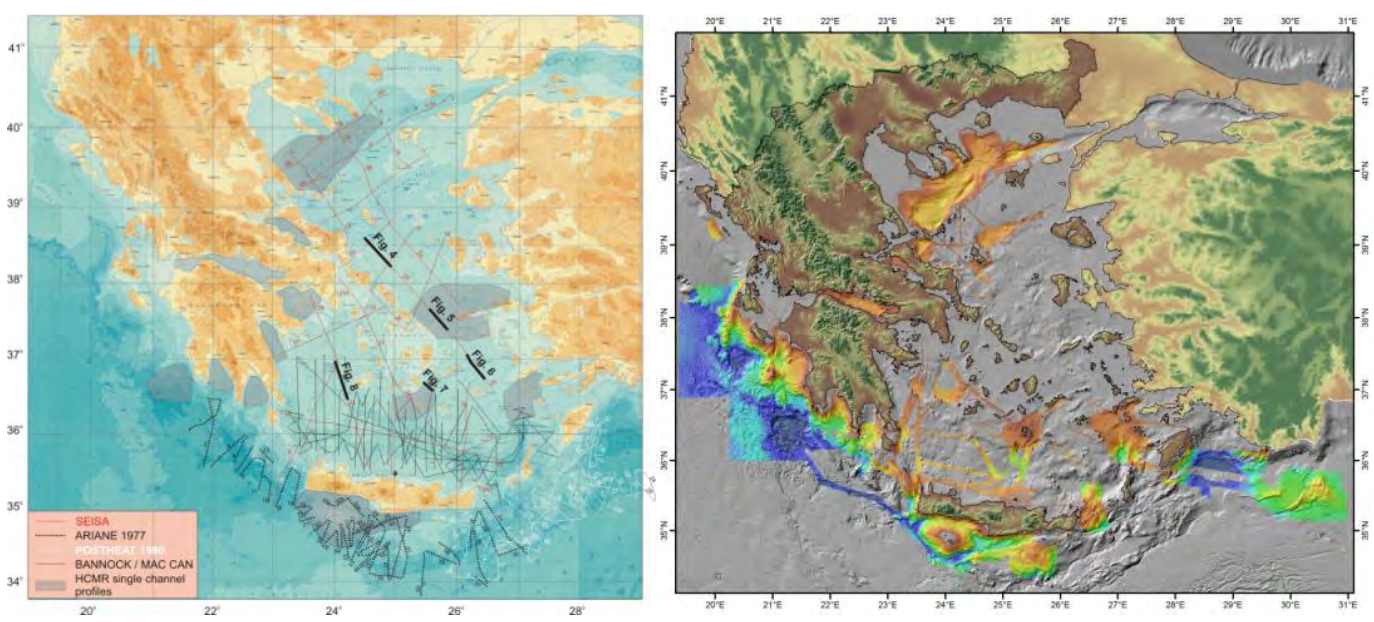

Figure 2(left) - Location map of continuous seismic profiles (multi channel, sparker) and single channel seismic profiles acquired during various cruises in the last 40 years in the Aegean Region and used for this study.

Figure 3(right) - Color-scaled swath bathymetry acquired by R/V AEGAEO (HCMR) since 2000 superimposed on gray-scaled shaded bathymetry (GEBCO) in the Aegean region. 
5. Re-interpretation of continuous seismic and sparker profiles obtained during the missions ARIANE 1977, POSTHEAT 1980, SEISA 1974 (Martin, 1987; Mascle \& Martin 1990), Bannock 1981 (Bartole et al, 1983), MAC CAN 1986 (Rossi et al, 1988) (Figure 2).

6. Interpretation of single channel seismic profiles obtained by HCMR during the last decades (Figure 2) in the frame of several projects and cruises: HERMES - south and southwest Crete, KM3Net - Southwest Peloponnese, THERA - Santorini area (Sigurdsson et al, 2006; Sakellariou et al, 2010), Gulf of Corinth (Moretti et al, 2004; Lykousis et al, 2007; Sakellariou et al, 2007a), AMPHITRITE - North Evia Gulf (Sakellariou et al, 2007b), North and South Ikarian Basins (Lykousis et al, 1995) and other (Figure 2).

7. Swath bathymetry data obtained in the Aegean Region by HCMR aboard R/V AEGAEO (Figure 3) and the swath bathymetry map of the Mediterranean Sea (Brossolo et al, 2012).

8. Review of published information and data on the active fault pattern in the offshore Aegean Region (Figure 8).

\section{Results}

\subsection{North Aegean Sea}

It is widely accepted that the North Aegean Trough is a transtensional basin developed along the right-lateral North Anatolian Fault (Angelier, 1979; Sengor, 1979; Hancock and Barka, 1980) since early Pliocene Pliocene (Armijo et al, 1999). Multi-channel and single channel profiles along with swath bathymetry data (Mascle \& Martin, 1990; Koukouvelas \& Aydin, 2002: Papanikolaou et al, 2002, 2006) indicate oblique opening of the basin marked by NE-SW strikeslip faults along the margins and within the basin, E-W strike slip faults in the basins and NW-SE normal faults along the Pelion and Athos margins.

The area between the North Aegean Trough and the Cyclades Plateau is regarded as a typical right-lateral strike-slip faulting regime (e.g. Mascle \& Martin, 1990; Taymaz et al., 1991; Kiratzi and Louvari, 2003). By using swath bathymetry and seismic profiling data we have mapped the most prominent Plio-Quaternary depocenters of this area with sediment thickness in excess of 0.5 seconds two-way travel-time and the major faults which bound them (Figure 8). The North Skyros Basin and the South Skyros Basin have developed along the southern branch of the North Anatolian Fault (Figure 4), while NW-SE trending apparently normal faults accommodate extension and subsidence of the basins. Cavo d' Oro and Lesvos Basins are two depocenters developed on the southern side of NE-SW running Cavo d' Oro - Lesvos Fault Zone (Figure 4). Like before, E-W to NW-SE trending normal faults contribute to the transtensional deformation and the creation of these two basins. Further south, a third major NE-SW trending fault zone separates the North Ikarian Basin and the Mykonos Basin to the north from the structural high of Ikaria, Samos and Mykonos Islands and the shallow ridge connecting them. Strike-slip sense of movement along this fault zone has been already proposed by Mascle \& Martin (1990) and by Lykousis et al (1995).

Focal mechanisms of shallow earthquakes occurred in this region (Kiratzi \& Louvari, 2003) strongly indicate that all three strike-slip fault zones mentioned above (south branch of North Anatolian Fault, Cavo d' Oro - Lesvos fault zone, North Ikarian fault zone) display right lateral sense of movement, like the North Anatolian Fault does.

\subsection{South Aegean Sea}

NE-trending strike-slip faults in the eastern part of the South Aegean Sea have been recognized by Mascle and Martin (1990) south of Santorini and Anafi. Piper \& Perissoratis (2003) have mapped pronounced $040^{\circ}$-trending set of faults in the area from Kos and Nisyros through Amorgos and Astypalea to Santorini with narrow basement ridges and abrupt basin inversion, which strongly suggests a strike-slip regime. Figure 6 shows the structure of the Amorgos Basin depocenter on the 
hangingwall of the apparent normal, NE-SW trending, S-facing Amorgos fault and one more, subvertical, apparently (left- or right-) lateral fault crosscutting the uplifted ridge. This fault pattern is in line with the interpretation proposed by Mascle \& Martin (1990) and Piper \& Perissoratis (2003).

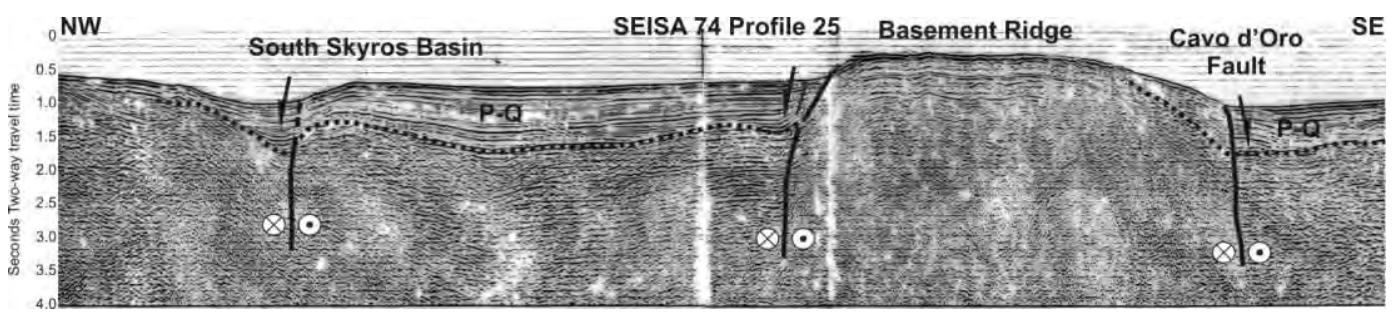

Figure 4 - Continuous seismic profile (SEISA 74) through the Southern Skyros Basin and Cavo D' Oro North Basin. Base of Plio-Quaternary deposits is shown as dotted line. Major basin bounding faults are subvertical and have been interpreted as dextral strike slip faults.

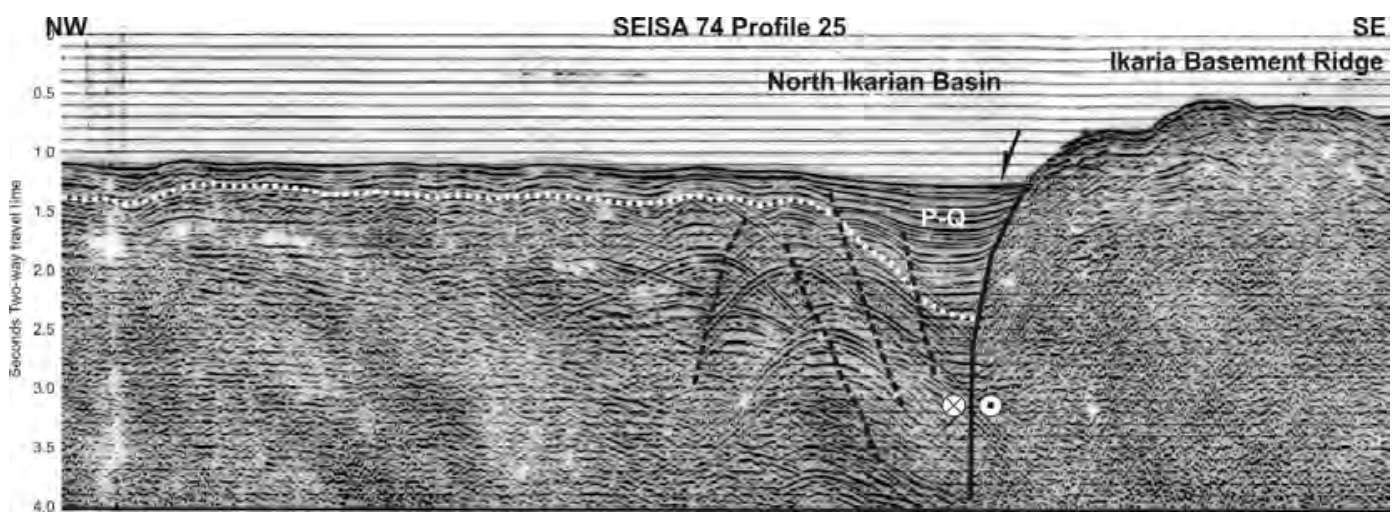

Figure 5 - Continuous seismic profile (SEISA 74) through the western part of the North

Ikarian Basin and the Basement Ridge between Mykonos and Ikaria. The North Ikarian fault is subvertical or dips steeply northward. The North Ikarian Basin has developed under the transtensional regime in the hangingwall of the fault.

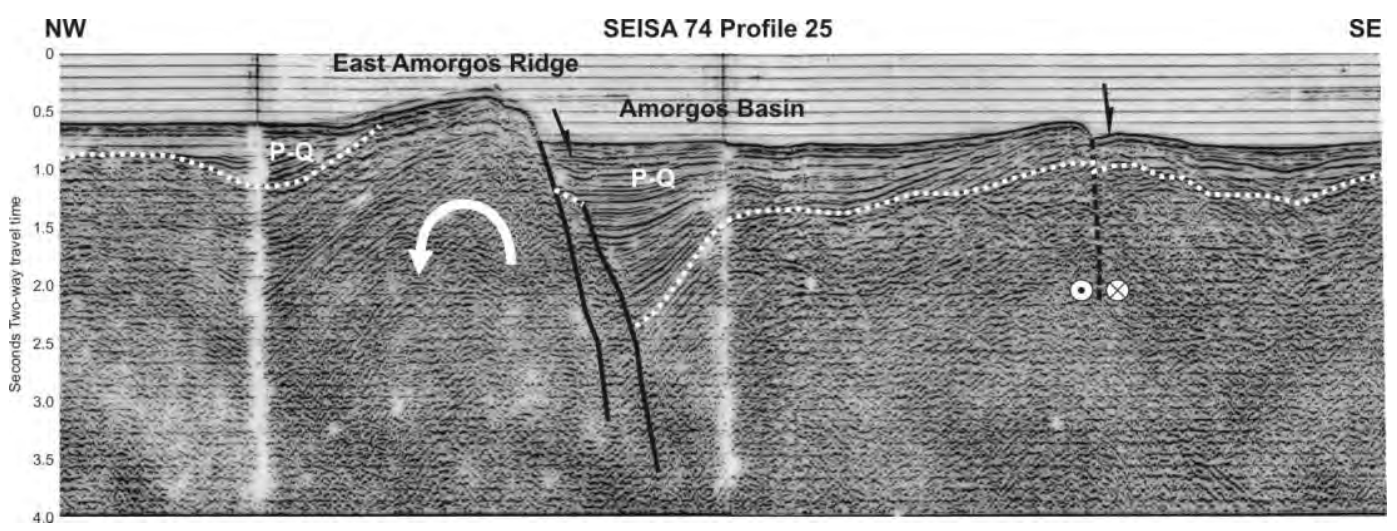

Figure 6 - Continuous seismic profile (SEISA 74) east of Amorgos. The E-W trending, Southfacing, east termination of Amorgos fault is apparently a normal fault which has accommodated extension of the transtensional Amorgos Basin. Note the vertical fault (pressumably sinistral strike-slip), which crosscuts the ridge located between Amorgos

(North) and Astypalea (South). 
In early nineties Papazachos and Panagiotopoulos (1993) have observed five clusters of strong, shallow and intermediate, earthquake epicentres corresponding to $060^{\circ}$ trending faults, which coincide with the volcanic fields at Sousaki, Methana, Milos, Santorini and Nisyros. Tibaldi et al (2008) suggest that Nisyros volcanic field has developed within a major NE-trending graben with strong evidence of left-lateral strike-slip component. In accordance to that, Sakellariou et al (2010) have proposed that the Santorini-Koloumbo volcanic field has developed within and along the transtensional NE-SW trending Anydros basin and that the volcanic centers of Christiana, Kameni and Koloumbo are aligned along a major strike-slip fault-zone. Piper \& Perissoratis (2003) have shown that the offshore area north and south of Milos is strongly offset by prominent N-S faults and at least one major NE-trending active fault and argue that this fault pattern is a consequence of NE-trending sinistral shear.

Figure 7 shows a re-interpreted seismic profile (modified after Mascle \& Martin, 1990) through the southern tectonic boundary of Mirtoon Basin and the NE-SW trending ridge southwest of Milos. Note that, with the exception of Antimilos, all volcanic centers of Milos field are aligned in NE-SW direction, parallel to the trend of the shear proposed by Piper \& Perissoratis (2003). In that sense, Mirtoon Basin may have formed within a transtensional regime and is bounded by NE-SW strike slip and NW-SE normal faults. Re-evaluation of the multi-channel seismic profiles from the western part of the South Aegean Sea indicates that the Argolikos and Antikythera Basins display similar structural configuration.

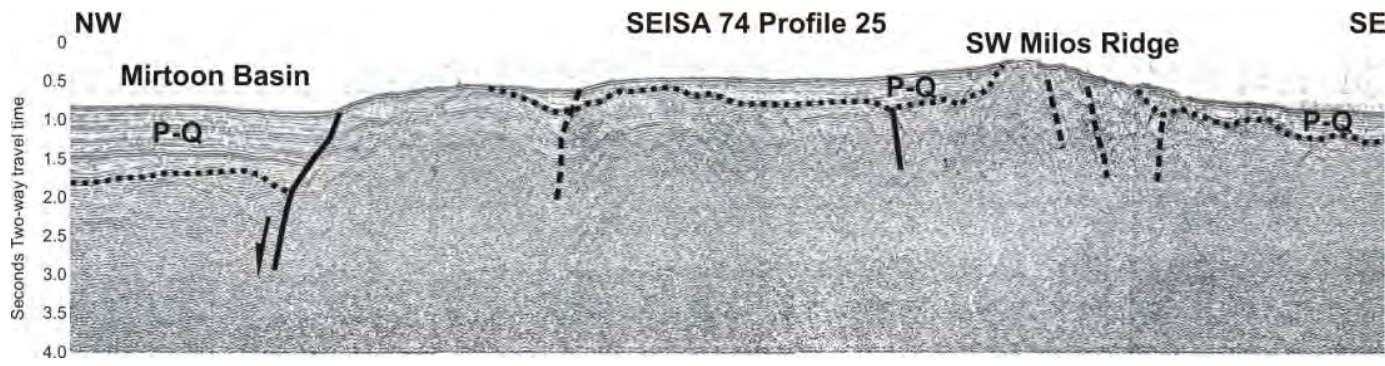

Figure 7 - Continuous seismic profile (SEISA 74) west of Milos. Note the sharp tectonic boundary of the Plio-Quaternary depocenter below the Myrtoon Basin towards S-SE and the structural high southwest of Milos, which is crosscut by subvertical faults.

In the eastern part of the South Aegean Sea Rossi et al (1986) recognized significant sinistral strike slip tectonics which led to the formation of major depocenters like Karpathos and Kamilonisi Basins (Fig. 8). Swath bathymetry data have revealed major, NE-SW trending, tectonomorphological structures, parallel or sub-parallel to the Plinian and Strabon trenches, as well as NNE-SSW oriented faulting. Kamilonosis and Syrna Basins are bounded by NE-SW trending major faults while Karpathos Basin, and the straits between Crete and Kassos and between Karpathos and Rhodes have developed due to the activity along NNE-SSW trending, apparently normal faults which to the north and south connect to NE-SW trending faults.

\subsection{Hellenic Arc and Trench}

Ten Veen \& Kleinspehn (2003) describe a very similar fault pattern on Crete: based on observation in Messara Basin they propose that Plio-Pleistocene basins both offshore and onshore Crete are controlled by sinistral $070^{\circ}$ strike-slip faults and secondary $020^{\circ}$ extensional oversteps. This is the case among others for the Iraklion Basin as well as for Eastern Crete where the NNE-SSW trending Ierapetra fault connects two major NE-SW oriented, offshore strike slip faults (Figure 8).

Swath bathymetry data along the Hellenic Arc south of Crete show that the outer edge of the Aegean microplate is sinistrally offset by two NE-SW trending strike-slip fault zones, the SE Cretan Trough and the Pliny Trough fault zones, while Strabo Trench marks the southeastern boundary of the microplate towards the East Mediterranean Ridge accretionary prism. Similar offset of the Hel- 
lenic Trench is observed SW of Crete, in line with the prolongation of the SW Cretan Trough fault zone. South and Southwest Peloponnese is characterized by NNW-SSE trending, predominantly normal faults which change progressively to the west to N-S direction.



Figure 8 - Simplified tectonic map of the Aegean Region with major faults and fault zones, sense of movement and main Plio-Quaternary depocenters shown in transparent blue color. Swath bathymetry and relief extracted from Brossolo et al (2012). Faults after Mascle \& Martin (1990), Piper \& Perissoratis (2003) and new data. NE-SW, curved, dashed, white line marks the Mid-Aegean Lineament. Abbreviations of basins: NAT: North Aegean Trough, NS: North Skyros, SS: South Skyros, Sk: Skopelos, L: Lesvos, CD: Cavo d' Oro, My: Mykonos, NI: North Ikaria, SI: South Ikaria, Mi: Mirtoon, Ar: Argolikos, Si: Sikinos, Chr: Christiana, Am: Amorgos, Sy: Syrna, Cr: Cretan, Ak: Antikythera, Ka; Kamilonissi, K: Karpathos, SWCR: Southwest Cretan Trough, SECR: Southeast Cretan Trough. 
Further north, west of Peloponnese and off the Ionian Islands, right lateral, NE-SW trending, strike slip faulting prevails, parallel to the Kephallonia Fault, as deduced from earthquake focal mechanisms (Kitatzi \& Louvari, 2003) and from seismic profiling and swath bathymetry data.

\section{Discussion - Conclusions}

Mascle \& Martin (1990) concluded that Late Miocene N-S extension in the South Aegean Sea shifted towards a NE-SW direction since Early Pliocene, perpendicular to the Ionian branch of the Hellenic trench, where pure convergent plate motion occurs. The former E-W structures have been slightly rotated to ENE-WSW direction progressively activated as transcurrent features (Martin, 1987). They suggested that the Aegean Sea can be viewed as a stretching continental domain cut into several ENE-WSW trending and elongated crustal terranes, all more or less independent of each other and moving progressively towards the southwest. Piper \& Perissoratis (2003) proposed that much of the deformation resulting from the interaction of the Eurasian, African and AnatolianAegean plates is taken up at the southern margin of the Aegean microplate, in the South Aegean arc. This deformation may have played an important role in the creation and distribution of volcanism along the Hellenic Volcanic Arc. The change in tectonic style observed since Early Pliocene corresponds to the time when the North Anatolian Fault broke into the North Aegean sea (Armijo et al., 1999). Ten Veen \& Kleinspehn (2003) believe that post-Miocene transtension has driven Hellenic forearc kinematics. Since Early Pliocene, incipient collision with Libyan promontory blocked further expansion of the Aegean plate south of western Crete and induced forearc slivers to be displaced northeastward and sheared sinistrally, as the Cretan-Rhodes forearc was simultaneously stretched.

Although this work is still in progress, our preliminary results suggest that deformation since Early Pliocene, when the North Anatolian Fault reached North Aegean, is strongly controlled by right and left lateral strike slip faulting distributed within the entire Aegean Region between the North Aegean Trough to the north and the southeastern branch of the Hellenic Arc to the south (Figure 8).

Transtensional deformation and development of major extensional structures in the Central and North Aegean Sea, Mainland Greece, Peloponnese and the Ionian branch of the Hellenic Arc is driven by right-lateral strike slip faulting following the kinematics of Kephallonia and North Anatolian Faults which form the northern tectonic boundary of the expanding Aegean microplate. The Central and Southern Aegean Sea along with the southern and southeastern branches of the Hellenic Arc are subject to left-lateral strike slip faulting, in accordance with the kinematics of the southeastern tectonic boundary of the Aegean microplate. The Mid-Aegean Lineament (Fig. 8), an imaginary line passing south of Samos and Ikaria Islands, over Central Cyclades plateau and through the West Cretan strait, marks the boundary between right-lateral (to the north) and left lateral (to the south) strike slip tectonics.

The southwestward expansion and stretching of the Aegean microplate during Plio-Quaternary takes place between two, more or less fixed, parallel to each other tectonic boundaries: (i) a rightlateral tectonic boundary to the north, marked by the Kephallonia and North Anatolian Faults and (ii) a left -lateral tectonic boundary to the south, marked by the southeastern branch of the Hellenic Trench (Pliny \& Strabo). Deformation of the Aegean microplate is mostly dominated by transtension, driven by NE-SW trending right-lateral (north) and left-lateral (south) strike slip fault zones and associated E-W and N-S normal faults.

\section{References}

Angelier J. 1979. Neotectonique de l'arc Egeen, These Doct., Univ. Paris VI.

Armijo R., Meyer B., King G., Rigo A. and Papanastassiou D. 1996. Quaternary evolution of the Corinth rift and its implications for Late Cenozoic evolution of the Aegean, Geophys. J. Int, $126,11-53$. 
Armijo R., Meyer B., Hubert A. and Barka A.1999. Westward propagation of the North Anatolian f ault into the northern Aegean: timing and kinematics, Geology, 27, 267-270.

Bartole R., Catani G., Lenardon G. and Vinci A.1983. Tectonics and sedimentation of the southern Aegean Sea, Boll. Oceanol. Teor. App., 1, 319-340.

Billiris H. et al.1991. Geodetic determination of tectonic deformation in central Greece from 1900 to 1988 , Nature, $350,124-129$.

Briole P. et al. 2000. Active deformation of the Corinth rift, Greece: Results from repeated Global Positioning System surveys between 1990 and 1995, J. Geophys. Res., 105, 25,605- 625.

Brosolo L., Mascle J. and Loubtrieu B. 2012. MorphoBathymetry of the Mediterranean Sea, Map 1/4.000.000. 1st Edition, Published by the Commission for the Geological Map of the Worl d (CGMW) and UNESCO), 2012

Clarke P. J. et al.1998. Crustal strain in central Greece from repeated GPS measurements in the int erval 1989-1997, Geophys. J. Int., 135, 195- 214.

Davies R., England P., Parsons B., Billiris H., Paradissis D. and Veis G. 1997. Geodetic strain of Greece in the interval 1892-1992, J. Geophys. Res., 102, 24,571-24,588.

Goldsworthy M., Jackson J. and Haines J. 2002. The continuity of active faults in Greece, Geophy s. J. Int., 148, 596- 618 .

Hancock P.L and Barka A.A. 1980. Plio-Pleistocene reversal of displacement on the North Anatoli an Fault Zone, Nature, 286(5773)5: 91-594.

Kiratzi A. and Louvari E. 2003. Focal mechanisms of shallow earthquakes in the Aegean Sea and $\mathrm{t}$ he surrounding lands determined by waveform modelling: a new database, J. Geodyn., 36 ( $1-2), 251-274$.

Kokkalas S., Xypolias P., Koukouvelas I. and Doutsos T. 2006. Postcollisional contractional and extensional deformation in the Aegean region. In Dilek, Y., and Pavlides, S., eds., Postcollisional tectonics and magmatism in the Mediterranean region and Asia: Geological Society of America, Special Paper 409, 97-123, doi: 10.1130/2006.2409(06).

Koukouvelas I. and Aydin A. 2002. Fault structure and related basins of the North Aegean Sea and its surroundings, Tectonics, 21, No. 5, 1046, doi:10.1029/2001TC901037, 2002

Le Pichon X. and Angelier J. 1979. The Hellenic Arc and trench system: A key to the neotectonic evolution of the eastern Mediterranean area, Tectonophysics, 60, $1-42$.

Le Pichon X. and Angelier J.1981. The Aegean Sea, Philos. Trans. R. Soc. London, Ser. A, 300, 35 $7-372$.

Le Pichon X., Chamot-Rooke N., Lallemant S., Noomen R. and Veis G.1995. Geodetic determinat ion of the kinematics of central Greece with respect to Europe, J. Geophys. Res., 100, 12,67 $5-12,690$.

Lykousis V., Anagnostou C., Pavlakis P., Rousakis G. and Alexandri M.1995. Quaternary sedimentary history and neotectonic evolution of the eastern part of the Central Aegean Sea, Greec e, Mar. Geol., 128, 59-71.

Martin L.1987. Structure et évolution récente de la meer égée: apports d'une étude par sismique ref lection, Thése Doct., Univ. Paris VI.

McClusky S. et al. 2000. Global Positioning System constraints on plate kinematics and dyna-mics in the eastern Mediterranean and Caucasus, J. Geophys. Res., 105, 5695-5719.

McKenzie D. P. 1972. Active tectonics of the Mediterranean region, Geophys. J. R. Astron. Soc, 3 0, 109- 185 .

McKenzie D. P. 1978. Active tectonics of the Alpine Himalayan Belt, the Aegean Sea and surroun ding regions, Geophys, J. R. Astron. Soc., 55, 217-252.

McKenzie D. P. and J. A. Jackson. 1983. The relationship between strain rates, crustal thicken-ing, paleomagnetism, finite strain and fault movements within a deforming zone, Earth \& Plan et. Sci. Lett., 65, 182-202.

McKenzie D. and Jackson J. 1986. A block model of distributed deformation by faulting, J. Geolo g. Soc. London, 143, 349-353.

Mascle J. and Martin L.1990. Shallow structure and recent evolution of the Aegean Sea: A synthesis based on continuous reflection profiles, Marine Geology, 94, 271-299. 
Mascle J., C. Huguen J., Benkhelil N., Chamot-Rooke E., Chaumillon J.-P., Foucher R., Griboulard A., Kopf G., Lamarche A., Volkonskaia J., Woodside T. and Zitter 1999. Images may show start of European-African Plate collision, EOS Trans., AGU 80 (1999) 421 428.

Mascle J. and Mascle G. 2012. Geological and Morpho-Tectonic Map of the Mediterranean Domain. Published by the Commission For The Geological Map Of The World (CGMW) and UNESCO.

Nyst M. and Thatcher W. 2004. New constraints on the active tectonic deformation of the Aegean, J. Geoph. Res., 109, B11406, doi:10.1029/2003JB002830, 2004

Papanikolaou D., Alexandri M., Nomikou P. and Ballas D. 2002. Morphotectonic structure of the western part of the North Aegean Basin based on swath bathymetry, Marine Geology, 190, 465-492

Papanikolaou D., Alexandri M. and Nomikou P. 2006. Active faulting in the north Aegean basin, Geol. Soc. America, Sp. Paper 409, 189-209, doi:10.1130/2006.2409(11).

Papanikolaou D.J. and Royden L.H. 2007. Disruption of the Hellenic arc: Late Miocene extension al detachment faults and steep Pliocene-Quaternary normal faults-Or what happened at Co rinth?, Tectonics, 26, TC5003, doi:10.1029/2006tc002007.

Papazachos B.C. and Panagiotopoulos D.G. 1993.Normal faults associated with volcanic activity a nd deep rupture zones in the southern Aegean volcanic arc, Tectonophysics, 220, 301-308.

Piper D.J.W. and Perissoratis C. 2003. Quaternary neotectonics of the South Aegean arc, Mar. Geo l., 198, 259-288.

Rossi S., Got H., Taviani M. and Martin L.1986. Elements structuraux de la mer de Crete orientale et du Golfe d'Antalya (Mediterranee orientale), Mem. Soc. Geol. It., 36, 153-164.

Sakellariou D., Lykousis V., Alexandri S., Kaberi H., Rousakis G., Nomikou P., Georgiou P. and Ballas D.2007a. Faulting, seismic-stratigraphic architecture and Late Quaternary evolution of the Gulf of Alkyonides basin - East Gulf of Corinth, Central Greece, Basin Research, 19/2, 273-295.

Sakellariou D., Rousakis G., Kaberi H., Kapsimalis V., Georgiou P., Kanellopoulos Th. and Lykousis V. 2007b. Tectono-sedimentary structure and late quaternary evolution of the north Evia gulf basin, Central Greece: preliminary results, Bulletin of the Geological Society of Greece, vol. XXXVII/1, p. 451-462.

Sakellariou D., Sigurdsson H., Alexandri M., Carey S., Rousakis G., Nomikou P., Georgiou P. and Ballas D. 2010. Active tectonics in the Hellenic Volcanic Arc: the Kolumbo submarine volcanic zone, Bulletin of the Geological Society of Greece, XLIII, No 2, 1056-1063

Sengor A.M.C. 1979. The North Anatolian transform fault: its age, offset and tectonic significance , J.Geol. Soc. London, 136, 269-282.

Sigurdsson H., Carey S., Alexandri M., Vougioukalakis G., Croff, K., Roman C., Sakellariou D., Anagnostou C., Rousakis G., Ioakim C., Gogou A., Ballas D., Misaridis T. and Nomikou P. 2006, Marine Investigations of Greece's Santorini Volcanic Field, EOS, Vol 87, 34.

Taymaz T., Jackson J. A. and McKenzie D. 1991. Active tectonics of the north and central Aegean Sea, Geophys. J. Int., 106, 433-490.

ten Veen, J.H. and Kleinspehn K.L. 2003. Incipient continental collision and plate-boundary curvature: Late Pliocene-Holocene transtensional Hellenic forearc, Crete, Greece, Journal of the Geological Society, London, Vol. 160, 2003, 161-181.

Tibaldi A., Pasquare F.A., Papanikolaou D. and Nomikou P. 2008. Tectonics of Nisyros Island, Greece, by field and offshore data, and analogue modeling, Journal of Structural Geology, $30,1489-1506$. 